\title{
SNOW AND ICE RESEARCH ON THE NORTH AMERICAN CONTINENT
}

\author{
By LoRne W. GoLD \\ (National Research Council of Canada, Division of Building Research)
}

SiNCE the end of the last war there has been a greatly increased interest on the North American continent in problems concerning snow and ice. This activity has been due mainly to the more intimate economic and strategic rôle played by these forms of water in the advance of technology and the development of northern regions. A feature of this expansion has been that many small interests have contributed, but until recently no central body was actively digesting and organizing the contributions. Organizations have now been set up to satisfy this need in both the United States and Canada. These organizations are the Snow and Ice Section of the Division of Building Research, National Research Council of Canada, working closely with the Council's Associate Committee on Soil and Snow Mechanics; and the Snow, Ice and Permafrost Research Establishment (SIPRE) of the Corps of Engineers, Defence Department of the United States.

Since there are many small groups at work in this field, this article cannot attempt to include all those participating. The work that is being done can be divided into sections, and for each section representative organizations will be named. It is hoped that the representative organizations named include those which are making the major contributions in each particular section.

\section{Problems}

Before the description of the work that is being done in the various sections, a few of the problems which are helping to shape this research will be mentioned. One of the principal problems is that of snow and ice surveys. This is important not only from the point of view of general knowledge but also because of the practical aspect in the North American economy of run-off, moisture accumulation, moisture reserves and transport over snow. For the results of these surveys to be of practical value, particularly in the engineering field, the records collected must be standardized in their terminology. To this end, the Associate Committee on Soil and Snow Mechanics of the National Research Council of Canada has taken an active interest in the proposed International Classification prepared by a committee of the International Union of Geodesy and Geophysics. ${ }^{1}$ Since snow and ice owe their origins to meteorological factors, no survey is complete until the relations which exist between these factors and the distribution, accumulation and ablation of the snow and ice are determined.

Due to the terrain of the northern part of the North American continent, the only suitable period in which to transport heavy equipment or produce into or out of many areas of this region is during the winter months. This immediately introduces the problems associated with oversnow transportation on both virgin and processed snow covers and the problems associated with transport over frozen lakes and rivers. It is well known that there is as yet no convenient method of measuring the bearing strength of an ice sheet over a lake or river.

Other problems which are of great significance on the North American continent are the formation of frazil and anchor ice and their effect on hydro-electric installations, the building up of pressure on dams by ice, the icing of objects such as aircraft and power lines, and the control of snow accumulation by use of snow removal units and fences.

\section{SNOW IN THE AIR}

Much work is being done in both Canada and the United States on the relationship between snow and meteorological factors. Groups active in this work in the United States are the Geophysics Research Division, Air Force Cambridge Research Center, Boston, Mass.; Signal Corps 
Engineering Laboratories, Fort Monmouth, New Jersey, and the Mount Washington Observatory, Gorham, New Hampshire. In Canada, this field is led by the Stormy Weather Group at McGill University, Montreal. Studies are also being carried out by the Defence Research Board of Canada and the National Research Council. One of the principal tools used in these studies is radar. Utilizing meteorological records, aircraft observations and radar, a relationship between snow-crystal types and the conditions under which the crystals are formed is beginning to appear.

\section{SNOW ON THE GRound}

The more extensive surveys of the snow cover on this continent are being carried out for the Associate Committee on Soil and Snow Mechanics of the National Research Council of Canada 2 and by the United States Weather Bureau in cooperation with SIPRE. Smaller surveys relating run-off to snow cover are being conducted in the United States by the Cooperative Snow Investigations ${ }^{3}$ (which include the Central Sierra Snow Laboratory, Upper Columbia Snow Laboratory, and Willamette Basin Snow Laboratory, administered by the United States Corps of Engineers), and the United States Department of Agriculture, Forest Service. In Canada a survey is conducted in British Columbia in the Fraser and Columbia Basins and Lower Coastal Areas by the Water Rights Branch, Department of Lands and Forests. ${ }^{4}$ The activities of these groups are coordinated by the Western Snow Conference and the Eastern Snow Conference.

Studies into the physical properties of snow are being conducted by the Snow and Ice Section of the National Research Council of Canada and by SIPRE in the United States. Many smaller projects in this phase are being undertaken by other groups but these groups are generally linked to the above-mentioned organizations either by contract or by direct contact. In studies on the physical properties of snow, the main stress is being placed on the investigation into those properties which show promise of describing the behaviour of snow under various types of loads at various stages of aging or processing. On this continent the emphasis is placed on those studies dealing with snow lying on level ground and being acted upon by external dynamic loads. Deformation of snow acting under its own weight (i.e., avalanches) is not as yet emphasized by most research groups because such major accumulations occur only in a relatively small portion of the continent. Avalanche studies are, however, being carried out by the Forest Service of the United States Department of Agriculture, ${ }^{*}$ in Utah, Colorado and Washington. ${ }^{5}$

\section{ICE Studies}

An ice survey has been initiated in Canada by the Geographical Branch of the Department of Mines and Technical Surveys in cooperation with the Defence Research Board of Canada. 6 Initially, Arctic regions are being emphasized, particularly those from which ice floes that make their way into shipping lanes originate.

At present, SIPRE is the organization most active in studies related to the physical properties of ice. It is cooperating closely with smaller groups, particularly educational institutes, which are conducting projects in this field. In Canada the Snow and Ice Section of the Division of Building Research, National Research Council, is also taking a more active interest and will initiate studies into the physical properties of ice in the near future. The main emphasis of this work is on the determination of the elastic and plastic properties of single ice crystals. The determination of most other physical properties is also included.

Many commercial organizations are involved in studies on ice. The Hydro-Electric Power Commission of Ontario has in progress an extended program to study the effects of ice pressure on dams. The American Ski Company of Clare, Michigan, is carrying out experiments on the sliding of materials on both ice and snow. In the United States, the Bureau of Reclamation of the Department of the Interior is also carrying out studies on ice, particularly in relation to ice pressure against dams. 
Before leaving this section on ice, mention should be made of the interest aroused on this continent by the recent observation of ice islands in the Arctic. These were first recorded by photography by the United States Air Force in 1946, and since that date extensive air surveys have been made in the Arctic regions by the United States Air Force and the Defence Research Board of Canada to track down the origin and life-cycle of these islands. ${ }^{7}$

\section{GLACIER ResEARCH}

In 1948 the Arctic Institute of North America launched Project Snow Cornice. ${ }^{8}$ It is at present carrying out extrusion flow studies on the Malaspina Glacier. Other ice masses on which they are making observations are the Saskatchewan Glacier and the ice cap of Baffin Island. The American Geographical Society has a program of glacier studies which centers on the Juneau Ice Fields in Alaska. 9 The Defence Research Board of Canada also has an active interest in glacier studies on this continent. In British Columbia, the Dominion Water and Power Bureau of the Department of Mines and Technical Surveys is conducting a survey of the glaciers in the Canadian Cordillera with the purpose of studying the effect of glacier variation on run-off. 10

\section{BIBLIOGRAPHIES}

When the program of snow research began to expand rapidly, it was realized that a complete survey of the literature on the subject should be made. SIPRE is at present undertaking such a survey. The Division of Building Research of the National Research Council of Canada has published a bibliography of articles on snow and ice which have appeared in a number of engineering journals and in the Transactions of the Royal Society of Canada to $195^{\circ} .^{11}$

\section{ACKNOWLEDGEMENTS}

The author wishes to record his appreciation to Mr. R. F. Legget, Director of the Division of Building Research, National Research Council of Canada, and to Mr. G. W. Rowley of the Arctic Section of the Defence Research Board of Canada, for guidance in the preparation of this paper.

MS. received 2I March 1953

\section{R E F E REN C E S}

I. Schaefer, V. J., and others. Entwurf einer internationalen Schneeklassifikation ausgearbeitet durch das Komitee für Schneeklassifikation, von V. J. Schaefer, G. J. Klein [und] M. R. de Quervain. Union Géodésique et Géophysique Internationale. Association Internationale d'Hydrologie Scientifique. Assemblée générale de Bruxelles, I95I. Tom. 1.

Louvain, [1952], p. I29-4I.
2. Pearce, D. C., and Gold, L. W. The Canadian snow survey, 1947-1950. Canada. National Research Council. Associate Committee on Soil and Snow Mechanics, Technical Memorandum No. 21, I951.

3. U.S. Army. Corps of Engineers and U.S. Weather Bureau. The cooperative snow investigations program. 1948.

4. British Columbia. Dept. of Mines and Forests. Water Rights Branch. Summary of snow survey measurements in British Columbia, I935-1952 inclusive. Victoria, B.C., 1952.

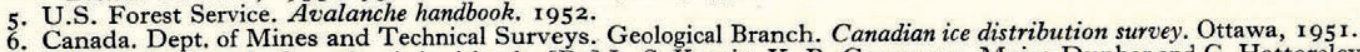

7. Koenig, L. S., and others. Arctic ice islands. [By] L. S. Koenig, K. R. Greenaway, Moira Dunbar and G. HattersleySmith. Arctic, Vol. 5, No. 2, 1952, p. 66-103.

8. Project "Snow Cornice", I950 and I95 I. Polar Record, Vol. 6, No. 45, 1953, p. 646-48.

9. Gilkey, Arthur K., and others. Progress report, Funeau Ice Field Research Project, Alaska, I952. New York, American Geographical Society, 1953.

so. Meek, V. Glacier observations in the Canadian Cordillera. Union Géodésique et Géophysique Internationale. Association Internationale d'Hydrologie Scientifique. Assemblée générale d'Oslo 19-28 août I948. Tom. 2. Louvain, [1950], p. $264-75$.

Ir. Pearce, D. C. A bibliography on snow and ice. Canada. National Research Council. Division of Building Research. Bibliography No. 1, 1951 . 